\title{
Learning Induces a CDC2-Related Protein Kinase, KKIAMRE
}

\author{
Hiroshi Gomi, ${ }^{1,2}$ William Sun, ${ }^{1,3}$ Caleb E. Finch, ${ }^{1}$ Shigeyoshi Itohara, ${ }^{2}$ Kenji Yoshimi, ${ }^{1,4}$ and \\ Richard F. Thompson 1
}

${ }^{1}$ Neuroscience Program, University of Southern California, Los Angeles, California 90089-2520, 2Laboratory for Behavioral Genetics, RIKEN Brain Science Institute, Wako, Japan, ${ }^{3}$ Metabasis Therapeutics, Inc., San Diego, California 92121, and ${ }^{4}$ Neuroscience Research Laboratories, Sankyo Co., Ltd., Tokyo 140, Japan

To elucidate molecular mechanisms in learning and memory, we analyzed expression of mRNAs in brains of rabbits undergoing eyeblink conditioning. Infusion of the transcription inhibitor actinomycin D into the cerebellar interpositus nucleus reversibly blocked learning but not performance of the conditioned response. Differential display PCR analysis of cerebellar interpositus RNAs from trained and pseudotrained rabbits identified a $207 \mathrm{bp}$ band that was induced with learning. The fragment was used to isolate a cDNA from a $\lambda \mathrm{gt} 11$ rabbit brain library containing a 1698 bp open reading frame. The deduced amino acid sequence contains the KKIAMRE motif, which is conserved among cell division cycle 2 (cdc2)-related kinases. These results suggest that there is a new category of cdc2-related kinases in the brain whose function may be important in learning and memory.

Key words: cerebellum; eyeblink conditioning; interpositus nucleus; RNA synthesis inhibition; learning-induced protein synthesis; KKIAMRE motif
Several lines of evidence have pointed to the cerebellum as a critical structure in the formation and storage of the memory trace in eyeblink conditioning (Thompson and Krupa, 1994). The neural output from the cerebellar (interpositus) deep nuclei to target structures forms the essential efferent pathway in this type of learning (Thompson, 1986; Krupa et al., 1993; Kim et al., 1996; Kim and Thompson, 1997). The cerebellum receives projections from mossy fibers and climbing fibers, which are thought to convey information about the conditioned stimulus (CS) and unconditioned stimulus (US), respectively. The CS and US signals converge in the cerebellar cortex and deep nuclei (Ito, 1984; Thompson, 1986). The convergence of these two inputs also fulfills the condition required for the induction of cerebellar long-term depression (LTD) (Ito, 1989; Linden and Conner, 1995).

Recent studies of eyeblink conditioning in various gene knockout mice have shown that deficits in cerebellar LTD correlated with impairment in eyeblink conditioning (Aiba et al., 1994; Shibuki et al., 1996). Purkinje cell degeneration ( $p c d)$ mutant mice, which lack cortical efferents to the deep nuclei, exhibited a marked impairment in eyeblink conditioning (Chen et al., 1996), but significant learning did occur. Substantial impairment in eyeblink conditioning has also been reported in rabbits with lesions limited to cerebellar cortex (Yeo et al., 1985b; Lavond et al., 1987; Lavond and Steinmetz, 1989a). In contrast, lesions of the cerebellar deep nuclei, in particular the dorsal anterior interpositus

\footnotetext{
Received April 8, 1999; revised Aug. 4, 1999; accepted Aug. 19, 1999.

This work was supported by National Institute on Aging (NIA) Grant AG00093 to W.S.; National Science Foundation Grant IBN 9215069, NIA Grant AF 05142, National Institute of Mental Health Grant 5P01-MH52194, and the Sankyo Co., Ltd. to R.F.T.; a research fellowship from the Japan Society for the Promotion of Science and a research grant from the Japanese Ministry of Education, Science, and Culture to H.G.; a research grant from RIKEN to S.I.; a fellowship from Sankyo Co., Ltd. to K.Y.; and NIA Grant 05142 to C.F.

Drs. Gomi and Sun contributed equally to this work.

Correspondence should be addressed to Richard F. Thompson, Neuroscience Program, University of Southern California, University Park, Los Angeles, CA 90089-2520. E-mail: thompson@neuro.usc.edu.

Copyright (C) 1999 Society for Neuroscience 0270-6474/99/199530-08\$05.00/0
}

nucleus (IN), completely prevented learning in naive animals and permanently abolished conditioned responses (CRs) in well trained animals (Lincoln et al., 1982; McCormick et al., 1982; Yeo et al., 1985a; Clark et al., 1992; Steinmetz et al., 1992; Krupa et al., 1993). Such effective lesions had no persisting effects on any aspect of the reflex unconditioned response (Steinmetz et al., 1992; Ivkovich et al., 1993). Finally, reversible inactivation of the IN during training completely prevented learning, but reversible inactivation of the immediate output from the IN, the superior cerebellar peduncle, and its target, the red nucleus, did not prevent learning at all (Clark et al., 1992; Clark and Lavond, 1993; Krupa et al., 1993; Nordholm et al., 1993; Krupa and Thompson, 1995, 1997). Thus, within the neural circuitry involved in eyeblink conditioning, the IN represents a critical locus for the acquisition and expression of the CR.

Much experimental evidence supports the idea that the synthesis of new RNAs or proteins are necessary for long-term changes in synaptic efficacy associated with long-term memory formation (Barondes and Cohen, 1966; Agranoff, 1967; Davis and Squire, 1984). For example, transcription and translation inhibitors blocked long-term facilitation (LTF) of the gill-withdrawal reflex in Aplysia (Montarolo et al., 1986). Long-term memory was further shown to require the activation of the transcription factor cAMP response element-binding protein (CREB) in some animal models (Kaang et al., 1993; Bourtchuladze et al., 1994; Yin et al., 1994). As for eyeblink conditioning, infusion of the protein synthesis inhibitor anisomycin into the IN was reported to interfere with conditioning in the rabbit (Bracha and Bloedel, 1996).

In this article, we report our studies to further unravel the molecular pathways underlying eyeblink conditioning. We first demonstrated that inhibition of RNA synthesis in the interpositus nuclear cells interfered with the acquisition of CRs. Next, we applied the method of differential display PCR (DD-PCR) (Liang and Pardee, 1992) to examine changes in gene expression that accompanied eyeblink conditioning. We identified an RNA molecule that was induced with conditioning. The cDNA cloning and 
sequence analyses showed that the expressed gene was the KKIAMRE kinase, a member of the cell division cycle 2 (cdc2)related and mitogen-activated protein (MAP) kinase family.

\section{MATERIALS AND METHODS}

Subjects. New Zealand white male rabbits (Oryctolagus cuniculus), weighing between 2 and $3 \mathrm{~kg}$ were individually housed at the University of Southern California Hedco Neuroscience Building vivarium with a $12 \mathrm{hr}$ light/cycle. The experiment was conducted during the light phase of the cycle. Rabbits had access to food and water ad libitum.

Infusion of actinomycin D. Stainless steel guide cannulas (25 ga) were implanted in the head of the animals with the tip fixed at $1.5-2.0 \mathrm{~mm}$ dorsal to the IN ipsilateral to the eye to be trained (left) (stereotaxic coordinates from lambda: $0.8 \mathrm{~mm}$ anterior, $5.2 \mathrm{~mm}$ lateral, and $14.0 \mathrm{~mm}$ ventral). Each guide cannula was filled with an inner stainless steel stylet designed to keep the guide cannula patent. Animals were given $5 \mathrm{~d}$ to recover from surgery. At infusion, the stylet was removed, and an inner cannula (31 ga) was inserted to the target locus. Delivery of fluids through the inner cannula was accomplished by a $10 \mu$ l Hamilton syringe driven by a syringe pump. Fluids were delivered to the target area at a rate of $0.38 \mu \mathrm{l} / \mathrm{min}$ for $2.6 \mathrm{~min}$. For the experimental group, $1 \mathrm{ng}$ of actinomycin D (ActD) (in $1 \mu$ l of vehicle) was infused daily 30 min before the start of each training session for $5 \mathrm{~d}(n=7)$. This dosage was determined in pilot studies; higher doses, e.g., $5 \mathrm{ng}$, caused permanent damage to the tissue. The animals were given $2 \mathrm{~d}$ rest and then trained for 5 more days without drug infusion. At training day 11, the experimental group was treated with $1 \mu \mathrm{g}$ of muscimol, which is known to reversibly inactivate the IN (Krupa and Thompson, 1997). For the control group, $1 \mu \mathrm{l}$ of artificial CSF (ACSF) (vehicle) was infused into the IN for $5 \mathrm{~d}(n=5)$. At day 6, control animals were infused with $1 \mathrm{ng}$ of ActD 30 min before training. On training day 7, $1 \mu \mathrm{g}$ of muscimol was infused.

Behavioral training. For the infusion experiments, all animals were subjected to eyeblink conditioning under the delay paradigm. The rabbits were allowed $1 \mathrm{~d}(1 \mathrm{hr})$ of habituation to the restrainer and the behavioral recording chamber. On the following day, paired tone-air puff training began. For each day, the training session began 30 min after drug infusion, and we gave only 10 trials per day (instead of the standard 100 trials per day; see below) to maximize the possibility that ActD was acting on the learning process before the long-term memory had been well established. The tone CS was a $350 \mathrm{msec}, 1000 \mathrm{~Hz}, 85 \mathrm{~dB}$ tone, and the air puff US was a $100 \mathrm{msec}$ puff of air ( 3 psi at the source) delivered to the rabbit's cornea, the CS and US coterminating. The mean intertrial interval (ITI) was $60 \pm 10 \mathrm{sec}$. Nictitating membrane (NM) conditioned responses were measured using a minitorque potentiometer attached to a small loop of monofilament nylon thread on the NM of the rabbit's left eye. Output of the potentiometer was digitized and recorded by computer. A conditioned response was defined as any NM extension response greater than $0.5 \mathrm{~mm}$ that occurred after tone onset but before air puff onset. The intratrial and intertrial timing, stimulus presentations, data collection, and analysis were performed by a personal computer with a program written in Forth and machine language (Lavond and Steinmetz, 1989b).

For DD-PCR analysis, four animals in the experimental group were trained under the standard delay paradigm in which each the daily training session consisted of 100 trials arranged into 10 blocks. Each block included one CS alone, one US alone, and eight CS-US paired trials. The ITI was $30 \pm 10 \mathrm{sec}$. The four animals in the control group were given an equal number of unpaired tone and air puff stimuli.

$R N A$ isolation and differential display. Once the paired group reached criterion (showing $>80 \% \mathrm{CR}$ ), all animals were killed by lethal injection with sodium pentobarbital (300 mg, i.v.) through the ear vein, and the brains were quickly removed and frozen. The cerebellum was then mounted on a cryostat and cut in the coronal plane until the deep nuclei just became visible. The deep nuclei tissue was removed and homogenized in TRIzol Reagent (Life Technologies, Gaithersburg, MD). RNA was isolated following the manufacturer's protocol. RNA samples were treated with RQ1 RNase-free DNase (Promega, Madison, WI) to remove chromosomal DNA.

Differential display was performed following the protocol of RNA Image kit (GenHunter, Nashville, TN). Two hundred nanograms of total RNA were used for reverse transcription (RT), followed by arbitrarily primed PCR using $\left[\alpha-{ }^{32} \mathrm{P}\right] \mathrm{dATP}(2000 \mathrm{Ci} / \mathrm{mmol}$; Amersham Pharmacia Biotech, Uppsala, Sweden) and Taq DNA polymerase (Promega). Sam- ples were then separated by electrophoresis on $6 \%$ polyacrylamide sequencing gels. The gels were dried under vacuum and exposed to x-ray films. DNA from the band of interest was extracted and reamplified by PCR following the manufacturer's instructions. The amplified DNA fragment was subcloned into the pCR-II vector of the TA Cloning System (Invitrogen, San Diego, CA). Multiple plasmid preparations were analyzed by EcoRI digestion, $1.5 \%$ agarose gel electrophoresis, and DNA sequencing using the Ladderman Sequence kit (TaKaRa, Tokyo, Japan).

Probe labeling and cDNA library screening. Plasmid DNA was digested with EcoRI, and the insert was separated from the vector by electrophoresis on $1.2 \%$ agarose. The insert band was excised from the gel and purified using the MERmaid kit (BIO 101, Inc., Carlsbad, CA). Twentyfive nanograms of the insert was radiolabeled with $\left[\alpha-{ }^{32} \mathrm{P}\right] \mathrm{dCTP}$ and Megaprime DNA Labeling System (Amersham Pharmacia Biotech). Approximately $5 \times 10^{5}$ plaques of rabbit brain $5^{\prime}$-Stretch Plus $\lambda \mathrm{gt} 11$ cDNA library (Clontech, Cambridge, UK) were screened using the differential display cDNA fragment. The isolated phage clones were purified, digested with EcoRI, and subcloned into pBluescript II vector (Stratagene, La Jolla, CA). Screening of the cDNA library was repeatedly performed using the appropriate probes prepared from primarily isolated cDNA clones.

Northern blot analysis. Poly $\left(\mathrm{A}^{+}\right)$RNA was purified from total RNA using PolyATract mRNA Isolation Systems (Promega). Denatured RNA samples $(3 \mu \mathrm{g})$ were subjected to electrophoresis in $1.0 \%$ agaroseformaldehyde gels, transferred to GeneScreen Plus hybridization transfer membranes (DuPont NEN, Boston, MA), cross-linked by UV irradiation, and hybridized with a ${ }^{32} \mathrm{P}$-labeled cDNA probe. Membranes were exposed to x-ray film at $-70^{\circ} \mathrm{C}$ with an intensifying screen.

$R T-P C R$ and Southern blot analysis. Two hundred nanograms of DNase-treated total RNA was reverse transcribed in a $20 \mu \mathrm{l}$ reaction mixture with the following composition: $5 \times$ RT buffer (Life Technologies), $10 \mathrm{~mm}$ DTT, $0.5 \mathrm{~mm}$ dNTPs, $100 \mathrm{~nm}$ oligo-dT 12-18 primer (Life Technologies), $40 \mathrm{U}$ of RNasin ribonuclease inhibitor (Promega), and $200 \mathrm{U}$ of MMLV reverse transcriptase (Life Technologies). After $60 \mathrm{~min}$ at $37^{\circ} \mathrm{C}$, the reaction was terminated by heating at $95^{\circ} \mathrm{C}$ for $5 \mathrm{~min}$ and stored at $-20^{\circ} \mathrm{C}$. PCR amplification was performed for $20-35$ cycles with the following thermocycle: $30 \mathrm{sec}$ at $94^{\circ} \mathrm{C}, 1 \mathrm{~min}$ at $60^{\circ} \mathrm{C}$, and $1 \mathrm{~min}$ at $72^{\circ} \mathrm{C}$ using GeneAmp PCR System 9600 (Perkin-Elmer, Emeryville, CA). The $20 \mu \mathrm{l}$ reaction mixture contained $0.5 \mathrm{U}$ Taq DNA polymerase, $2 \mu \mathrm{l}$ of RT mixture, $250 \mathrm{~mm}$ dNTPs, $2.0 \mu \mathrm{M} \mathrm{MgCl}$, and $250 \mathrm{~nm}$ each primer. The amplified DNA was separated by agarose gel electrophoresis and transferred to GeneScreen Plus hybridization membrane. The filters were hybridized with a ${ }^{32} \mathrm{P}$-labeled cDNA probe. To evaluate gene expression level, the cloned cDNA of the desired sequence were serially diluted $\left(2 \times 10^{6}\right.$ to $2 \times 10^{1}$ copies $)$ and processed in the exact manner as the other samples. PCR primers were 5'-TTGCAGAAGAAGGAACGACA- $3^{\prime}$ for the sense primer and $5^{\prime}$-TGTCGTTCCTTCTTCTGCAA-3' for the antisense primer to generate a 399 bp [nucleotides 18462244 of rabbit (Rbt) KKIAMRE]. As an internal control for the quality of RNA and RT samples, the rabbit neurofilament-L (NF-L) cDNA (nucleotides 948-1646) (Soppet et al., 1991) was amplified using the sense primer 5'-AAGGCCAAGACCCTGGAGAT-3' and the antisense primer 5'-TCAATCTTTCTTCTTGGTTG-3'.

Immunohistochemistry. Rabbits were deeply anesthetized with sodium pentobarbital and fixed with $800 \mathrm{ml}$ of $4 \%$ ice-cold paraformaldehyde in $0.1 \mathrm{M}$ sodium phosphate buffer, $\mathrm{pH} 7.4$, via cardiac perfusion after washing out blood with $500 \mathrm{ml}$ of physiological saline perfusion. The brain was removed and post-fixed with the same fixative overnight at $4^{\circ} \mathrm{C}$. Tissues were dissected and equilibrated in $30 \%$ sucrose in $0.1 \mathrm{M}$ sodium phosphate buffer, $\mathrm{pH}$ 7.4. Frozen sections (30- $\mu$ m-thick) were cut using a cryostat. The sections were washed with PBS containing $0.1 \%$ Triton $\mathrm{X}-100$ (PBS/Tx) and the nonspecific reaction blocked by immersion in $0.3 \%$ hydrogen peroxide and $10 \%$ normal donkey serum. Subsequently, the sections were reacted with a 1:250 dilution of an anti-KKIAMRE (N-20) antibody (catalog \#sc-6287; Santa Cruz Biotechnology, Santa Cruz, CA) for overnight at $4^{\circ} \mathrm{C}$. After repeated washes with PBS/Tx, the sections were incubated with a 1:2000 dilution of a biotinylated anti-goat secondary antibody (Chemicon, Temecula, CA). Immunohistochemical detection was performed with an avidin-biotin-peroxidase technique using the Vectastain $\mathrm{ABC}$ kit and $\mathrm{DAB}$ substrate kit obtained from Vector Laboratories (Burlingame, CA). 


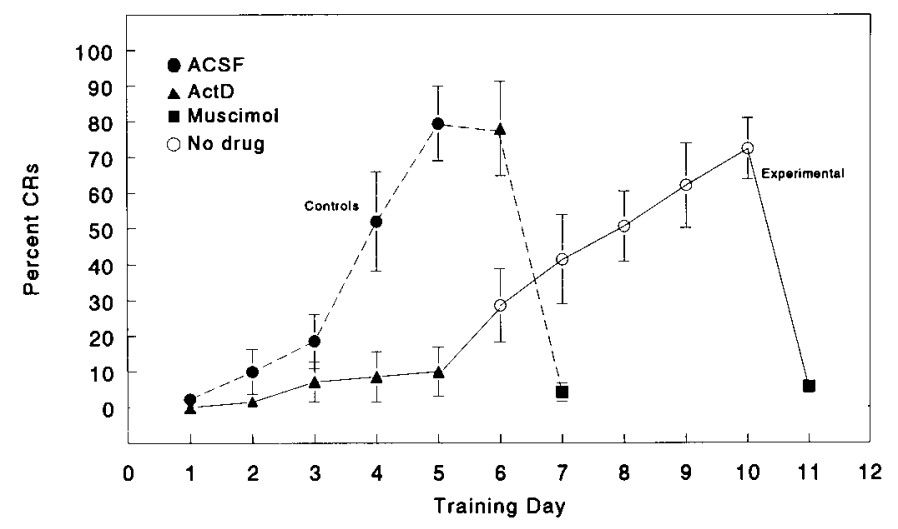

Figure 1. Inf usion of ActD into the left IN inhibited eyeblink conditioning (left eye). Graph shows average percent CRs for control $(n=5)$ and experimental $(n=7)$ animals. All subjects were trained with only 10 paired CS-US trials per day. The control group $(\bullet)$ received ACSF infusion for the first 5 training days, $1 \mathrm{ng}$ of ActD on the sixth training day $(\boldsymbol{\Delta})$, and 1 $\mu \mathrm{g}$ of muscimol on day $7(\boldsymbol{\square})$. The experimental group (A) received infusion of $1 \mathrm{ng}$ of ActD each day for $5 \mathrm{~d}$. After $2 \mathrm{~d}$ rest, experimental animals were trained without drug infusion for 5 more days $(\bigcirc)$. At day 11 , the experimental group was infused with $1 \mu \mathrm{g}$ of muscimol (ם).

\section{RESULTS}

\section{Actinomycin D reversibly inhibited eyeblink conditioning}

Rabbits underwent eyeblink training (10 paired trials per day) 30 min after infusion of $1 \mathrm{ng}$ of ActD or ACSF into the dorsal anterior IN ipsilateral to the trained eye. An ANOVA was completed for the first $5 \mathrm{~d}$ of training for both groups (ACSF and ActD); the groups differed significantly $\left(F_{(1,10)}=15.4 ; p<0.003\right)$; days of training was significant $\left(F_{(4,40)}=17.9 ; p<0.0001\right)$, as was the interaction $\left(F_{(4,40)}=14.2 ; p<0.0001\right)$. As shown in Figure 1, rabbits receiving ACSF infusion reached criteria $(>80 \% \mathrm{CR})$ at the end of $5 \mathrm{~d}$ of training (ANOVA over training days $1-5, F_{(4,16)}$ $=19.9 ; p<0.01)$. Infusion of ActD at day 6 into these control animals did not prevent the expression of acquired CRs. Inf usion of $1 \mu \mathrm{g}$ of muscimol on day 7 completely abolished the CRs (Krupa et al., 1993). Rabbits receiving ActD infusions exhibited low levels of CRs at the end of $5 \mathrm{~d}$ (ANOVA over training days $1-5, F_{(4,24)}=1.35$; NS). After $2 \mathrm{~d}$ rest, animals in the experimental group were trained without drug infusion, and they showed a gradual increase of CRs (ANOVA over training days $\left.6-10, F_{(4,24)}=7.61 ; p<0.01\right)$. Most animals in the experimental group reached criterion after $5 \mathrm{~d}$ of additional training without drug infusion. At day 11, the experimental group was infused with $1 \mu \mathrm{g}$ of muscimol, which completely abolished the expression of CRs. Cannula placements were all in or within close approximation to the dorsal anterior interpositus nucleus and were effective, as demonstrated by muscimol abolition of the CRs in all animals (Krupa et al., 1993).

\section{Identification and cloning of rabbit KKIAMRE}

Four experimental rabbits trained with our standard CS-US paired stimuli schedule (100 trials per day) showed over $80 \%$ CRs after $4 \mathrm{~d}$ of training, whereas the four control rabbits trained with unpaired CS-US stimuli did not show significant levels of CRs (Fig. 2). All subjects were killed immediately after the day 4 training session, and their brains were removed. RNA was isolated from the IN and overlying cortex (hemispheric lobule VI) because these regions represent essential sites for eyeblink conditioning (Thompson and Krupa, 1994). DD-PCR was performed

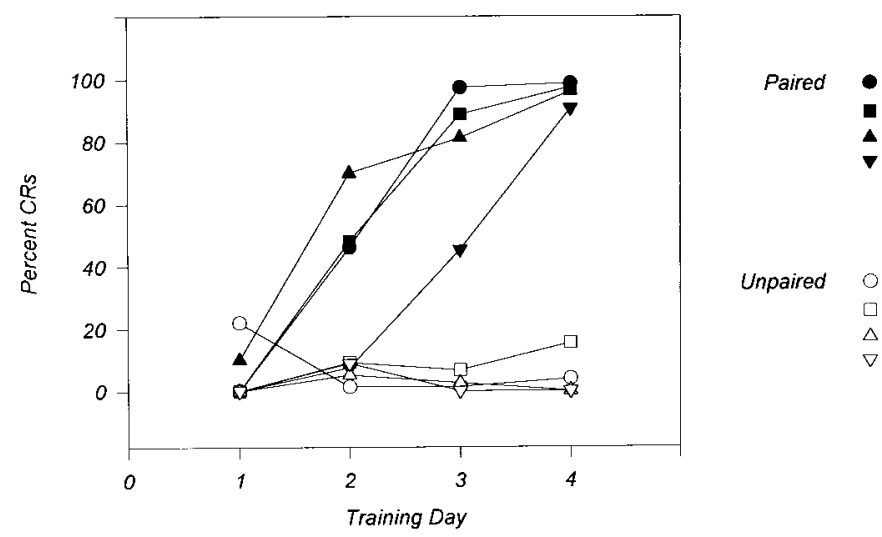

Figure 2. Learning curves for animals used in DD-PCR analysis. Conditioned animals (filled symbols) were trained with the standard delay procedure (see Materials and Methods), 100 trials per day. Control animals (open symbols) received unpaired CS and US stimuli.
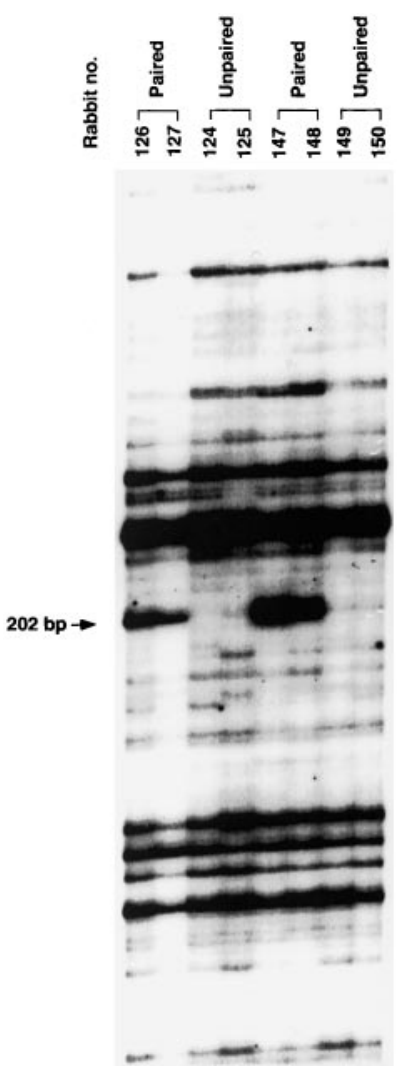

Figure 3. DD-PCR patterns of RNAs isolated from the cerebellar deep nuclei of CS-US paired and unpaired stimuli conditioned rabbits. Differential display reactions were performed using $5^{\prime}$-AAGCTTTTTTTTTTTA-3' as an anchored primer and $5^{\prime}$-AAGCTTTGGTCAG-3' as a random arbitrary primer. The arrow indicates a PCR-amplified $207 \mathrm{bp}$ cDNA fragment that appeared to be induced with paired training.

by using 48 different sets of primers. Among the bands of PCRamplified fragments from paired and unpaired deep nuclei mRNA, a 207 bp cDNA fragment was identified that was differentially expressed in the cerebellar deep nuclei (Fig. 3). The nucleotide sequence of this cDNA fragment did not share homology with any other known sequences. Approximately $5 \times 10^{5}$ plaques of a $\lambda$ gt11 rabbit brain cDNA library (Clontech) was screened using the DD-PCR cDNA fragment as the probe and 


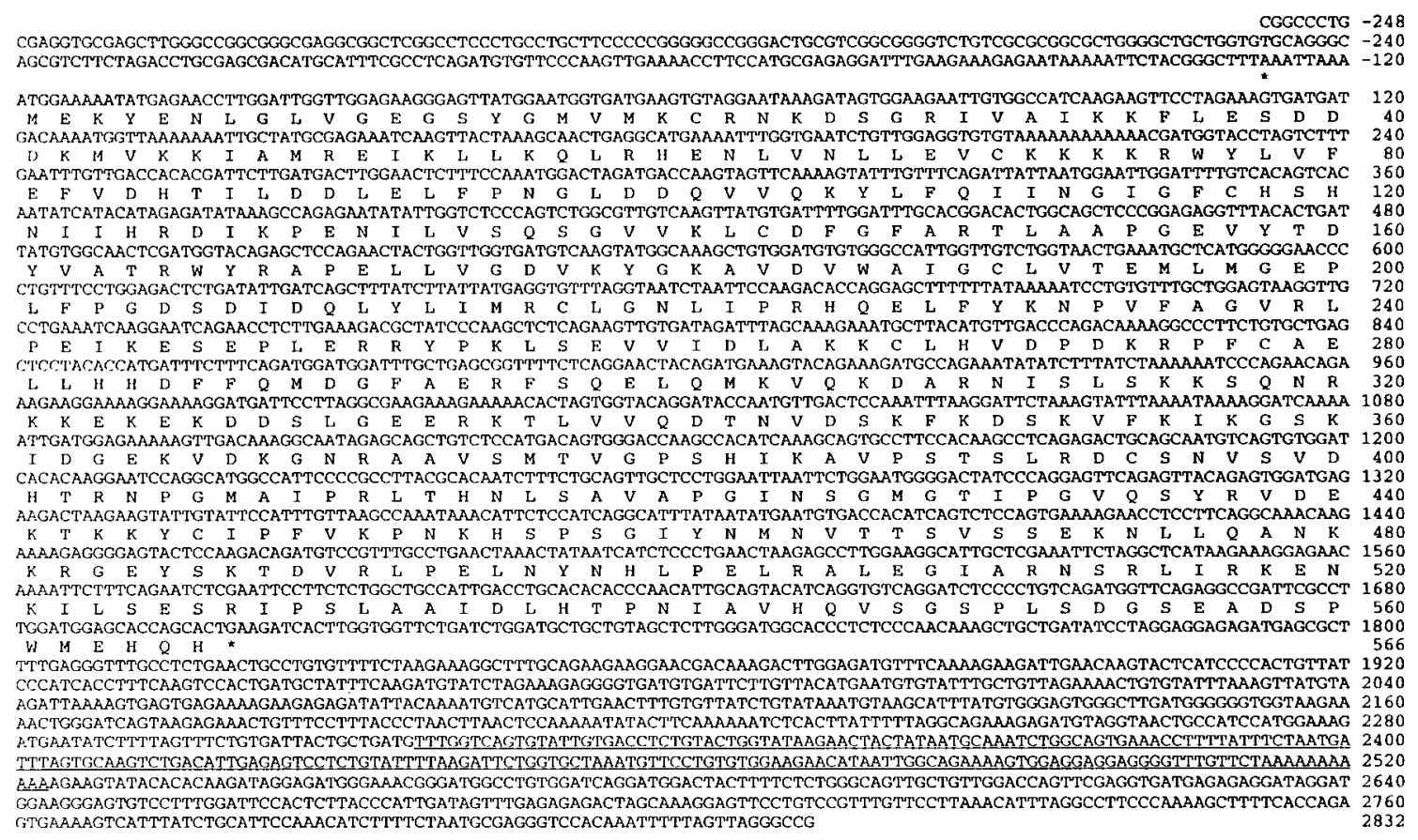

Figure 4. Nucleotide and predicted amino acid sequence of Rbt KKIAMRE kinase. The deduced 566 amino acid sequence of the open reading frame is shown in standard single letter code. Asterisks show the in-frame stop codons in the $5^{\prime}$ and $3^{\prime}$ untranslated regions. The 207 bp fragment near the $3^{\prime}$ end identified by DD-PCR is underlined.

eight overlapping clones were isolated. Eight additional overlapping clones were isolated by screening with a more $5^{\prime}$ region of the cDNA. A full-length cDNA (3080 bp) was constructed from the overlapping clones, and it contains a 1698 bp open reading frame. Figure 4 shows the nucleotide sequence and predicted amino acid sequence of the cDNA. Comparison of the predicted amino acid sequence of the cDNA with the GenBank database (BLAST fileserver) revealed high homology with human p56 protein kinase (p56 KKIAMRE), which was reported to be related to cdc2 and MAP kinases (Taglienti et al., 1996). These proteins share $97.2 \%$ amino acid identity in the kinase domain (Fig. 5). The molecule we isolated was thus named Rbt KKIAMRE kinase. Although the Rbt KKIAMRE was very similar to that of p56 KKIAMRE, Rbt KKIAMRE had a stretch of extra 77 amino acids near the $3^{\prime}$ region. KKIAMRE shares homology with Ser/Thr kinases p42 KKIALRE (Meyerson et al., 1992), cdc2 (Lee and Nurse, 1987), cdk2 (Tsai et al., 1991), and members of the MAP kinase family, extracellular signal-regulated kinase-1 (Boulton et al., 1990), c-Jun N-terminal protein kinase-1 (Derijard et al., 1994), and p38 (Lee et al., 1994) (Fig. 5).

\section{Regional expression of Rbt KKIAMRE}

The expression pattern of Rbt KKIAMRE mRNA was examined in various tissues and in the brain regions of naive rabbits by Northern blot analysis. Rbt KKIAMRE was expressed predominantly in the brain, but expression was also evident in kidney, lung, and testis (Fig. 6). The tissue-specific expression pattern of Rbt KKIAMRE was thus similar to that of p56 KKIAMRE (Taglienti et al., 1996). For the Rbt KKIAMRE, Northern blot revealed a single transcript of $\sim 4 \mathrm{~kb}$ in each tissue (Fig. 6), whereas two major transcripts were observed in adult testis and kidney for p56 KKIAMRE (Taglienti et al., 1996). The fine distribution of the expression in the brain was further evaluated by immunohistochemistry. For the immunohistochemical detec- tion of rabbit KKIAMRE, we used an anti-KKIAMRE antibody (catalog \#sc-6287; Santa Cruz Biotechnology), which is prepared against to the N-terminal 20 amino acids of p56 human KKIAMRE as an immunogen (Taglienti et al., 1996). Because the N-terminal 20 amino acids sequence of Rbt KKIAMRE was identical to p56 human KKIAMRE, the antibody was applicable for immunohistochemical study in rabbit. Expression of Rbt KKIAMRE was observed in neurons of the various brain regions. Figures $7 A-E$ represent the immunostaining with antiKKIAMRE antibody in the cerebellar deep nuclei, hippocampus, cerebral cortex, and cerebellar Purkinje cells of the rabbit brain. Expression was also evident in several brainstem nuclei, in particular the vestibular, trigeminal, and facial nuclei (Fig. $7 F, G$ ). Strong immunoreactivity was observed predominantly in the nucleus and perinuclear zone of neurons and moderately in the cytoplasm.

\section{Conditioning-dependent induction of Rbt KKIAMRE in the IN}

Previous studies indicate that cerebellar cortex and IN are both involved in eyeblink conditioning. To determine the site in which the Rbt KKIAMRE may participate in eyeblink conditioning, we examined the level of transcripts of the Rbt KKIAMRE in these tissues of the eyeblink conditioned animals (100 trials per day; 4 d) by a semi-quantitative RT-PCR-Southern blot analysis. RNAs isolated from the left cerebellar deep nuclei and cerebellar cortex were reverse transcribed using oligo-dT primer, and PCR was performed with primer sets designed for Rbt KKIAMRE and rabbit NF-L cDNAs. To confirm conditioning-induced expression initially found by the $207 \mathrm{bp}$ fragment, a part of KKIAMRE mRNA outside of the 207 bp fragment was amplified by PCR. As shown in Figure 8 (top), cerebellar deep nuclei from animals trained with CS-US paired stimuli (lanes $P 1, P 2$ ) showed nearly 10 times increased expression of Rbt KKIAMRE when 


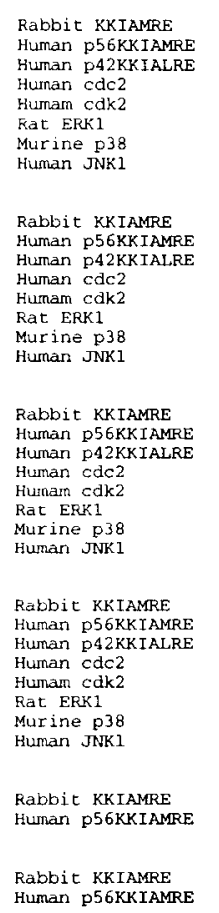

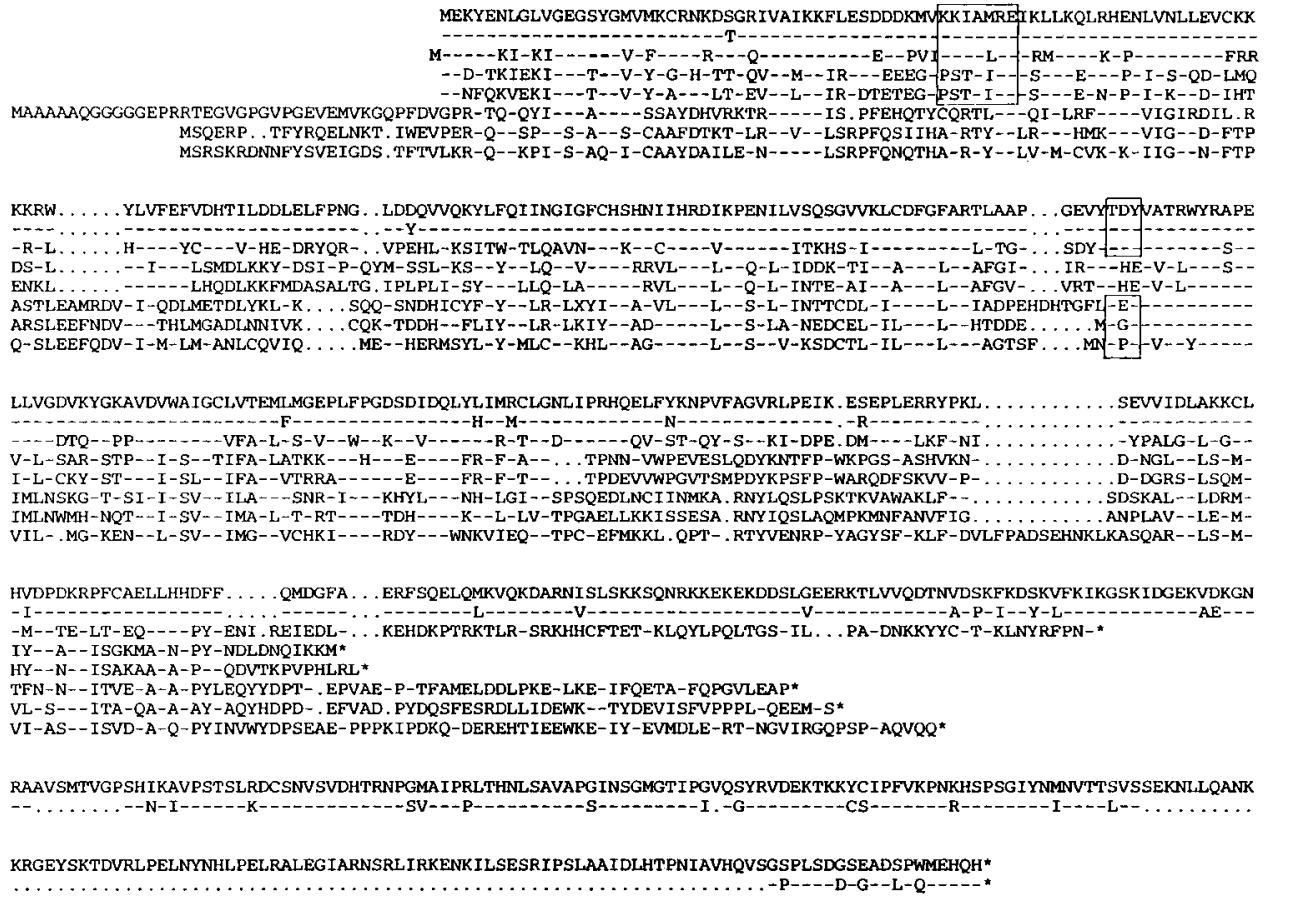

MEKYENLGLVGEGSYGMUMKCRNKDSGRIVAIKKFLESDDDKMVKK IAMRG KLLLKQLRHENLVNLLEVCKK

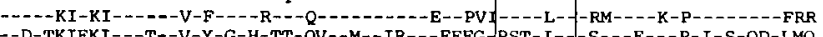
D-TKIEKI---T--V-Y-G-H-TT-QV--M--IR---EEEG PST-I-- $-S---E--P-I-S-Q D-L M Q$

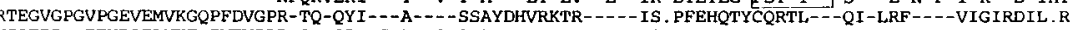
MSQERP. . TFYRQELNKT. IWEVPER-Q--SP--S-A--S-CAAFDTKT-LR--V--LSRPFQSIIHA-RTY--LR---HMK---VIG--D-FTP FEFVDHTILDDLELFPNG . .LDDQVVQKYLFQI INGIGFCHSHNI IHRDIKPENILVSQSGVVKLCDFGFARTLAAP . . GEVYTDYVVATRWYRAPE KKW. . . . . -R-L $\ldots \ldots$ H- . ENKL ........-----LHQDLKKFMDASALTG. I PLPLI-SY---LLQ-LA-----RVL---L--Q-L-INTE-AI--A---L--AFGV- . . VRT--HE-V-L----ASTLEAMRDV-I-QDLMETDL YKL-K . . . SQQ-SNDH ICYF-Y--LR-LXYI--A-VL---L--S-L-INTTCDL-I----L--IADPEHDHTGFL-E-------

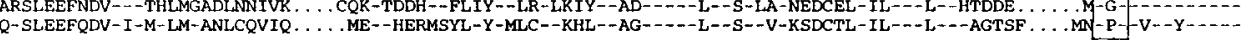

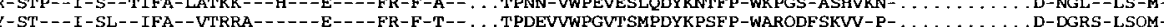

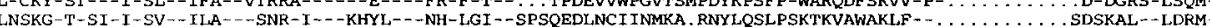
VIL- MG-KEN--L-SV--IMG--VCHKI----RDY---WNKVIEQ--TPC-EFMKKL . QPT- . RTYVENRP-YAGYSF-KLF-DVLFPADSEHNKLKASQAR--LS-M-

HVDPDKRPFCAELLHHDFF . . . . . QMDGFA . . ERFSQELQMKVQKDARNI SLSKKSQNRKKEKEKDDSLGEERKTLVVQDTNVDSKFKDSKVFK IKGSKIDGEKVDKGN -M--TE-LT-EQ- - -PY-ENI . REIEDL- . . . KEHDK PTRKTLR-SRKHHCFTET-KLQYLPQLTGS-IL . . PA-DNKKYYC-T-KLNYRFPN-

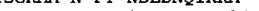

TFN-N--ITVE-A-A-PYLEOYYDPT- EPVAE-P-TFAMTLDDLPKE-LKE-IFOETA-FOPGVLEAP

NTA-

RAAVSMTVGPSH IKAVPSTSLRDCSNVSVDHTRNPGMAI PRLTHNLSAVAPGINSGMGTIPGVQSYRVDEKTKKYCIPFVKPNKHSPSGIYNMNVTTSVSSEKNLLQANK KRGEYSKTDVRLPELNYNHLPELRALEGIARNSRLIRKENKILSESRIPSLAATDLHTPNIAVHQVSGSPLSDGSEADSPWMEHQH*
$\ldots \ldots \ldots \ldots \ldots \ldots \ldots \ldots \ldots \ldots \ldots \ldots \ldots \ldots \ldots \ldots \ldots \ldots \ldots \ldots \ldots \ldots \ldots \ldots \ldots \ldots$
.

Figure 5. Comparison of the predicted amino acid sequences of the cdc2-related kinases and MAP kinases. Dashes indicate residues identical to Rbt KKIAMRE, dots represent gaps in the sequence to optimize the alignment, and asterisks indicate stop codons. Boxes indicate the region of the conserved PSTAIRE motif in cdc2 used for the kinase nomenclature, as well as the conserved threonine $(T)$ and tyrosine $(Y)$ residues, the regulatory phosphorylation sites required for MAP kinase activation.

compared with those of animals trained with unpaired stimuli (lanes U1, U2). However, no difference in expression was observed in the cerebellar cortex between these two groups. PCR with NF-L primers using the same cDNA templates showed comparable levels of NF-L expression in the deep nuclei and cortex of both trained and unpaired pseudotrained animals (Fig. 8 , bottom). These results indicated that the increased expression of Rbt KKIAMRE in the brain was specific for conditioned animals and that the increased expression was localized to the cerebellar deep nuclei.

\section{DISCUSSION}

\section{Associative motor learning requires new RNA synthesis}

Our results show that inf usion of ActD, an RNA synthesis inhibitor, into the cerebellar interpositus nucleus over the course of eyeblink conditioning completely prevents learning, consistent with a report that protein synthesis inhibition in this nucleus interfered with eyeblink conditioning (Bracha and Bloedel, 1996). The present results thus strongly support the idea that associative motor learning requires new RNA synthesis. Because eyeblink conditioning typically requires many trials over several days, it is a learning paradigm apparently lacking an obvious short-term component. In addition, once a rabbit is well trained, the CR is robust, not easily extinguished, and retained for months (Lavond et al., 1984). Indeed, acquisition of the conditioned NM response shows similar temporal characteristics to those found in other associative learning tasks in which formation of long-term memory is required. This is consistent with the idea that long-term memory requires long-lasting changes in synaptic efficacy, which most likely requires synthesis of new RNA-proteins. Accordingly, infusion of ActD into the interpositus nucleus inhibited

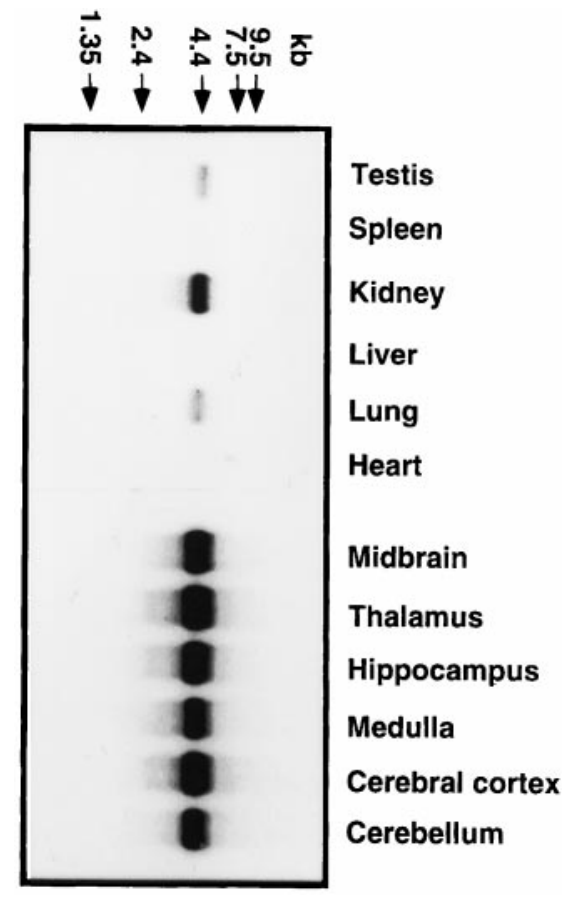

Figure 6. Northern blot analysis of Rbt KKIAMRE expression in naive rabbit. Three micrograms of poly $\left(\mathrm{A}^{+}\right)$RNA extracted from each brain region and peripheral tissue were hybridized with a 876 bp cDNA fragment in the coding region. Molecular weight standards are indicated by arrows on the top. 


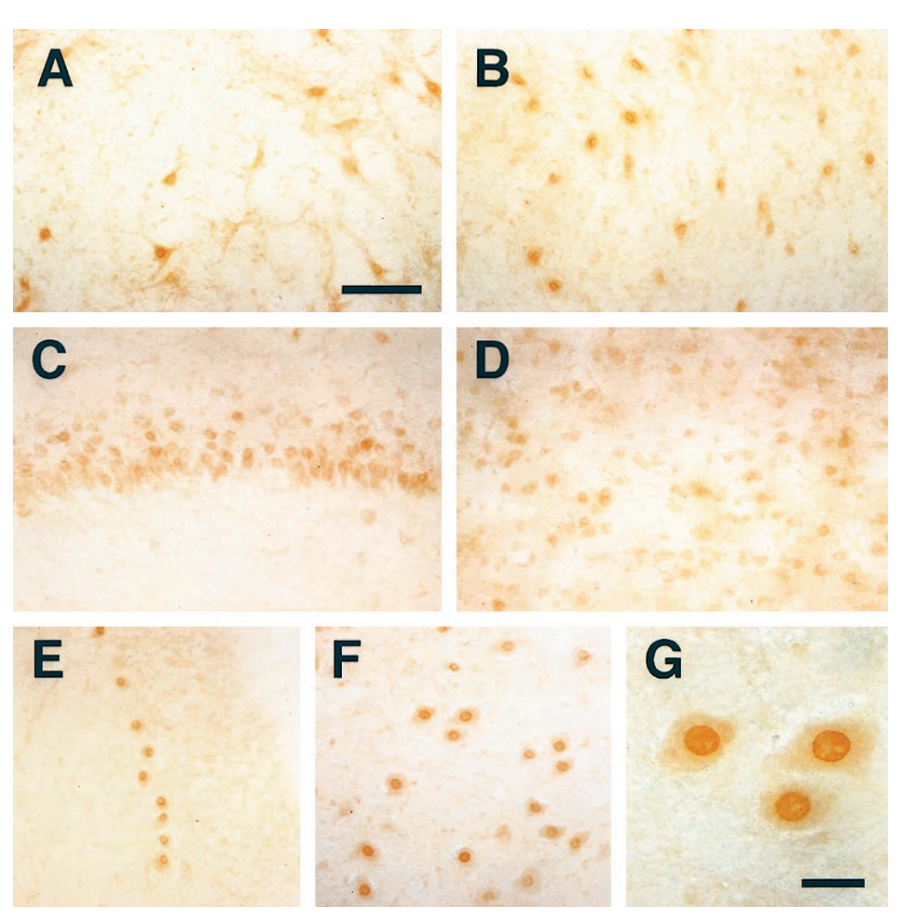

Figure 7. Immunohistochemistry of KKIAMRE labeled with an antiKKIAMRE antibody. KKIAMRE expression was detected in neurons of various brain regions: interpositus nucleus $(A)$ and dentate nucleus $(B)$ in the cerebellar deep nuclei, hippocampal CA3 $(C)$, cerebral cortex $(D)$, cerebellar Purkinje cell $(E)$, and facial nuclei in the brain stem $(F) . G$ shows immunoreactive neurons in the facial nuclei with a higher magnification having a strong signal in the nucleus. Scale bars: $A-F, 100 \mu \mathrm{m} ; G$, $25 \mu \mathrm{m}$.

eyeblink conditioning. However, once the animal was conditioned, infusion of ActD had no effect on the performance of CRs. Thus, new mRNA synthesis is essential for acquisition but not expression of the learned response. These results further support our hypothesis that eyeblink conditioning involves longterm changes in the synapses within the cerebellar interpositus nucleus. In the following experiments, we attempt to determine the mRNA that is expressed in the interpositus nucleus during conditioning.

\section{Eyeblink conditioning induces a cdc2-related kinase in the brain}

Differential display analysis indicated that eyeblink conditioning led to an increased expression of KKIAMRE, a cdc2-related kinase, in the cells of deep cerebellar nuclei. In this DD-PCR analysis, we set limited conditions for the comparison of the gene expression in rabbits. The subject animals were trained with CS-US paired stimuli and control unpaired stimuli, and the RNAs were isolated from the deep cerebellar nuclei after $4 \mathrm{~d}$ training when over $80 \%$ of CRs were shown in animals with CS-US paired stimuli. Thus, the induction of KKIAMRE we found might be involved in this restricted region of the brain and only in the late stage of learning. One of the advantages of DD-PCR analysis is to profile a number of genes, and it is reasonable to think that a set of genes change their expression patterns in complex plastic changes. The detectable changes of gene expression analyzed by DD-PCR would depend on which comparable controls are selected. Although we identified one gene, KKIAMRE induction in our analysis in the eyeblink conditioning, the result does not negate the possibility that other
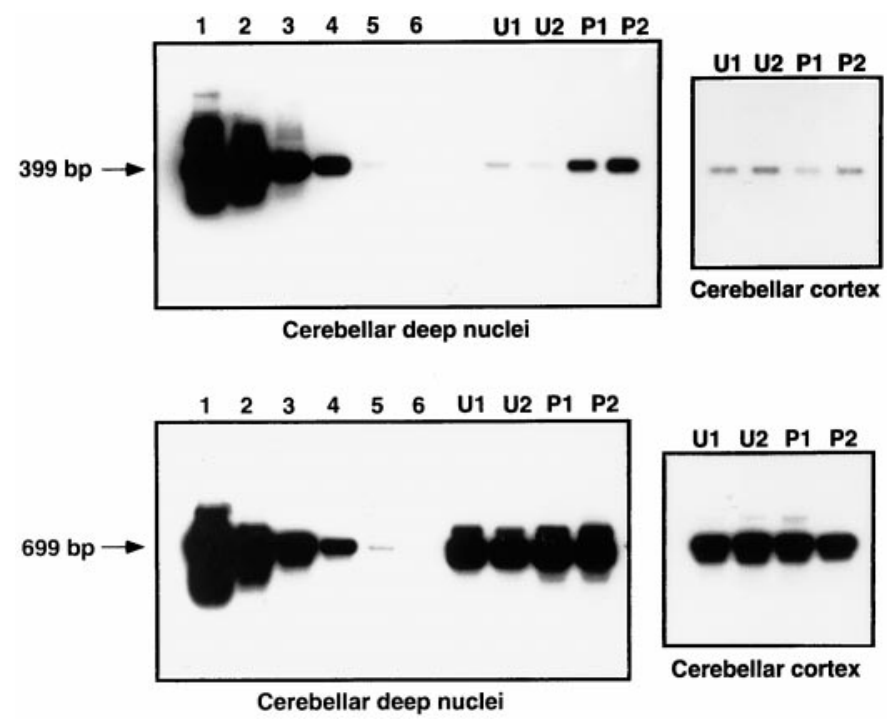

Figure 8. RT-PCR-Southern blot analysis of gene expression in eyeblink conditioned rabbit. Top, Expression of Rbt KKIAMRE in the cerebellar deep nuclei and cerebellar cortex. A 399 bp RT-PCR product was hybridized with a 677 bp cDNA fragment in the $3^{\prime}$ noncoding region. Lanes $U 1$ and $U 2$ represent RNA from rabbits trained with unpaired stimuli and lanes $P 1$ and $P 2$ RNA from well conditioned rabbits. For semiquantitative analysis, serial dilutions of the control cDNA plasmid was used for PCR: $2 \times 10^{6}$ copies (lane 1), $2 \times 10^{5}$ copies (lane 2), $2 \times 10^{4}$ copies (lane 3), $2 \times 10^{3}$ copies (lane 4), $2 \times 10^{2}$ copies (lane 5), and $2 \times 10^{1}$ copies (lane $6)$. PCR was performed for 30 cycles. Bottom, Expression of a control gene NF-L using the same RNA samples as in $A$. A 699 bp fragment was amplified from 27 PCR cycles and hybridized with an $855 \mathrm{bp}$ cDNA probe in the coding region. Copy number of plasmids used for positive control PCR (lanes 1-6) was the same as mentioned above.

genes are induced at different learning phases of the eyeblink conditioning. Therefore, we would propose that KKIAMRE is one of the candidate genes that are closely related to some aspects of associative learning.

KKIAMRE belongs to cdc2-related kinases and MAP kinase families in a broad sense (Taglienti et al., 1996). The amino acid motif KKIAMRE, like the KKIALRE motif, is a highly conserved motif related to PSTAIRE of the cyclin-dependent kinases (Meyerson et al., 1992). The Thr-Xaa-Tyr (Thr-Asp-Tyr in the case of KKIAMRE and KKIALRE) phosphorylation motif, which is required for MAP kinase activation and regulated by the upstream dual-specificity kinases (Nishida and Gotoh, 1993), is conserved in the region between protein kinase subdomains VII and VIII of Rbt KKIAMRE.

Our result raises interesting questions because cdc2 and MAP kinases are primarily involved in cell cycle regulation. Because neurons in the mammalian brain are postmitotic, these kinases may serve a different function in the brain. Recent reports described a neuronal cdc2-like kinase, cdk5, together with a p25 regulatory subunit, which could phosphorylate neurofilament and tau proteins and may be involved in neuronal sprouting and development (Lew and Wang, 1995; Tang et al., 1996). An attractive hypothesis is that induction of KKIAMRE may be a signal for cellular growth, which would lead to extension of neuronal and glial dendritic process or glial proliferation-migration. Such long-lasting synaptic changes would be suitable for the establishment of a long-term memory trace. Hence, KKIAMRE, like $\mathrm{Cdk} 5$, may belong to a novel family of kinases that play a critical role in cognitive functions of the brain. 
Another subgroup of this kinase family (Fig. 5), the MAP kinase, was reported to be implicated in a signal transduction pathway that controls synaptic LTF in Aplysia (Bailey et al., 1997; Martin et al., 1997). MAP kinase possibly regulates LTF by phosphorylation of transcription factors, such as Aplysia homologs of CREBs CREB1, CREB2, and $\mathrm{C} / \mathrm{EBPb}$ in the nucleus, as well as by phosphorylation of Aplysia neural cell adhesion molecule homolog in the synaptic vicinity. Furthermore, p42, a MAP kinase isoform, was reported to be activated in the CA1 area after stimuli that induced long-term potentiation (LTP) in rat hippocampal slices (English and Sweatt, 1996). These observations suggest that MAP kinases are important regulators of synaptic plasticity in neurons. Thus, if Rbt KKIAMRE functions in the same way as MAP kinases, then KKIAMRE plays a role in long-term synaptic changes that may underlie memory consolidation in the brain.

Other types of kinases in the brain have been shown to play an essential role in different learning paradigms. Much recent attention has been given to the $\mathrm{Ca} 2{ }^{+}$-calmodulin-dependent protein kinase II, which has been shown to be necessary for hippocampal LTP, as well as spatial learning tasks (Silva et al., 1992; Soderling, 1993; Mayford et al., 1996; Barria et al., 1997). Similary, the cAMP-dependent protein kinase pathway and the associated molecule CREB have been implicated in long-term memory in several animal models of associative learning (Kaang et al., 1993; Bourtchuladze et al., 1994; Yin et al., 1994; Abel et al., 1997). Protein kinase $\mathrm{C}$ has been demonstrated to play an important role in hippocampal LTP (Wang and Feng, 1992; Abeliovich et al., 1993; Leahy et al., 1993) and cerebellar LTD (Crepel and Krupa, 1988; Linden and Connor, 1991), two proposed neural mechanisms underlying associative learning in animals. Because Rbt KKIAMRE is expressed in the hippocampal pyramidal cell layer, its function may also be important in hippocampal-dependent learning, such as spatial learning.

Although the protein-gene structure of Rbt KKIAMRE is a homolog of human KKIAMRE, its cellular function may be different from that of human. The cellular distribution of KKIALRE protein in the human brain was shown with antibodies to the C-terminal subregion (Yen et al., 1995). KKIALRE was present in fibrous astrocytes in the white matter, perivascular and subpial spaces, as well as Bergmann glia in the cerebellum, but not in neurons. In contrast, the Rbt KKIAMRE is expressed in neurons, as evidenced by immunohistochemistry (Fig. 7). This difference clearly implies multiple roles of this kinase in the brain. Further work will be required to uncover the role of Rbt KKIAMRE and its signaling pathway in associative motor learning, as well as other types of associative learning tasks. Although we have shown that new mRNA synthesis is required for conditioning and KKIAMRE is expressed during conditioning, it is still not clear whether KKIAMRE is necessary for the acquisition of conditioning. Disruption of the Rbt KKIAMRE gene in mice would further clarify the link between this kinase function in the brain and behavior.

\section{REFERENCES}

Abel T, Nguyen PV, Barad M, Deuel TA, Kandel ER (1997) Genetic demonstration of a role for PKA in the late phase of LTP and in hippocampus-based long-term memory. Cell 88:615-626.

Abeliovich A, Paylor R, Chen C, Goda Y, Silva AJ, Stevens CF, Tonegawa S (1993) Modified hippocampal long-term potentiation in PKC gamma-mutant mice. Cell 75:1253-1262.
Agranoff BW (1967) Memory and protein synthesis. Sci Am 216:115-122.

Aiba A, KanoM, ChenC, Stanton ME, Fox GD, HerrupK, Zwingmann TA, Tonegawa S (1994) Deficient cerebellar long-term depression and impaired motor learning in mGluR1 mutant mice. Cell 79:377-388.

Bailey CH, Kaang B-K, Chen M, Martin KC, Lim C-S, Cassadio A, Kandel ER (1997) Mutation in the phosphorlation sites of MAP kinase blocks learning-related internalization of apCAM in Aplysia sensory neurons. Neuron 18:913-924.

Barondes SH, Cohen HD (1966) Puromycin effect on successive phases of memory. Science 151:594-595.

Barria A, Muller D, Derkach V, Griffith LC, Soderling TR (1997) Regulatory phosphorylation of AMPA-type glutamate receptors by CaMKII during long-term potentiation. Science 276:2042-2045.

Boulton TG, Yancopoulos GD, Gregory JS, Slaughter C, Moomaw C, Hsu J, Cobb MH (1990) An insulin-stimulated protein kinase similar to yeast kinases involved in cell cycle control. Science 249:64-67.

Bourtchuladze R, Frenguelli B, Blendy J, Cioffi D, Schutz G, Silva AJ (1994) Deficient long-term membory in mice with a targeted mutation of the cAMP-responsive element-binding protein. Cell 79:59-68.

Bracha V, Bloedel JR (1996) The multiple-pathway model of circuits subserving the classical conditioning of withdrawal reflexes. In: The acquisition of motor behavior in vertebrates (Bloedel JR, Ebner TJ, Wise SP, eds), pp 175-204. Cambridge, MA: MIT.

Chen L, Bao S, Lockard JM, Kim JJ, Thompson RF (1996) Impaired classical eyeblink conditioning in cerebellar-lesioned and Purkinje cell degeneration (pcd) mutant mice. J Neurosci 16:2829-2838.

Clark RE, Lavond DG (1993) Reversible lesions of the red nucleus during acquisition and retention of a classically conditioned behavior in rabbit. Behav Neurosci 107:264-270.

Clark RE, Zhang AA, Lavond DG (1992) Reversible lesions of the cerebellar interpositus nucleus during acquisition and retention of a classically conditioned behavior. Behav Neurosci 106:879-888.

Crepel F, Krupa M (1988) Activation of protein kinase C induces a long-term depression of glutamate sensitivity of cerebellar Purkinje cells. An in vitro study. Brain Res 458:397-401.

Davis HP, Squire LR (1984) Protein synthesis and memory. A review. Psychol Bull 96:518-559.

Derijard B, Hibi M, Wu I-H, Barrett T, Su B, Deng T, Karin M, Davis RJ (1994) JNK1: a protein kinase stimulated by UV light and Ha-Ras that binds and phosphorylates the c-Jun activation domain. Cell 76:1025-1037.

English JD, Sweatt JD (1996) Activation of p42 mitogen-activated protein kinase in hippocampal long term potentiation. J Biol Chem 271:24329-24332.

Ito M (1984) The cerebellum and neural control. New York: Appleton Century-Crofts.

Ito M (1989) Long-tem depression. Annu Rev Neurosci 12:85-102.

Ivkovich D, Lockard JM, Thompson RF (1993) Interpositus lesion abolition of the eyeblink CR is not due to effects on performance. Behav Neurosci 107:530-532.

Kaang BK, Kandel ER, Grant SG (1993) Activation of cAMPresponsive genes by stimuli that produce long-term facilitation in Aplysia sensory neurons. Neuron 10:427-435.

Kim J, Thompson RF (1997) Cerebellar circuits and synaptic mechanisms involved in classical eyeblink conditioning. Trends Neurosci 20:177-181.

Kim JJ, Chen L, Bao S, Sun W, Thompson RF (1996) Genetic dissections of the cerebellar circuitry involved in classical eyeblink conditioning. In: Gene targeting and new developments in neurobiology (Nakanishi S, Silva AJ, Aizawa S, Katsuki M, eds), pp 3-15. Tokyo: Japan Scientific Societies.

Krupa DJ, Thompson RF (1995) Inactivation of the superior cerebellar peduncle blocks expression but not acquisition of the rabbit's classically conditioned eyeblink response. Proc Natl Acad Sci USA 92:5097-5101.

Krupa DJ, Thompson RF (1997) Reversible inactivation of the cerebellar interpositus nucleus completely prevents acquisition of the classically conditioned eyeblink response. Learn Mem 3:545-556.

Krupa DJ, Thompson JK, Thompson RF (1993) Localization of a memory trace in the mammalian brain. Science 260:989-991.

Lavond DG, Steinmetz JE (1989a) Acquisition of classical conditioning without cerebellar cortex. Behav Brain Res 33:113-164.

Lavond DG, Steinmetz JE (1989b) An inexpensive interface for IBM $\mathrm{PC} / \mathrm{XT}$ and compatibles. Behav Res Methods Instrum Comput 21:435-440. 
Lavond DG, McCormick DA, Thompson RF (1984) Nonrecoverable learning deficit. Physiol Psychol 12:103-110.

Lavond DG, Steinmetz JE, Yokaitis MH, Thompson RF (1987) Reacquisition of classical conditioning after removal of cerebellar cortex. Exp Brain Res 67:569-593.

Leahy JC, Luo Y, Kent CS, Meiri KF, Vallano ML (1993) Demonstration of presynaptic protein kinase $\mathrm{C}$ activation following long-term potentiation in rat hippocampal slices. Neuroscience 52:563-574.

Lee JC, Laydon JT, McDonnell PC, Gallagher TF, Kumar S, Green D, McNulty D, Blumenthal MJ, Heys JR, Landvatter SW, Strickler JE, McLaughlin MM, Siemens IR, Fisher SM, Livi GP, White JR, Adams JL, Young PR (1994) A protein kinase involved in the regulation of inflammatory cytokine biosynthesis. Nature 372:739-746.

Lee MG, Nurse P (1987) Complementation used to clone a human homologue of the fission yeast cell cycle control gene cdc2. Nature 327:31-35.

Lew J, Wang JH (1995) Neuronal cdc2-like kinase. Trends Biochem Sci 20:33-37.

Liang P, Pardee AB (1992) Differential display of eukaryotic messenger RNA by means of polymerase chain reaction. Science 257:967-971.

Lincoln JS, McCormick DA, Thompson RF (1982) Ipsilateral cerebellar lesions prevent learning of the classically conditioned nictitating membrane/eyelid response. Brain Res 242:190-193.

Linden DJ, Connor JA (1991) Participation of postsynaptic PKC in cerebellar long-term depression in culture. Science 254:1656-1659.

Linden DJ, Connor JA (1995) Long-term synaptic depression. Annu Rev Neurosci 18:319-357.

Martin KC, Michael D, Rose JC, Barad M, Casadio A, Zhu H, Kandel ER (1997) MAP kinase translocates into the nucleus of the presynaptic cell and is required for long-term facilitation in Aplysia. Neuron 18:899-912.

Mayford M, Bach ME, Huang YY, Wang L, Hawkins RD, Kandel ER (1996) Control of memory formation through regulated expression of a CaMKII transgene. Science 274:1678-1683.

McCormick DA, Clark GA, Lavond DG, Thompson RF (1982) Initial localization of the memory trace for a basic form of learning. Proc Natl Acad Sci USA 79:2731-2735.

Meyerson M, Enders GH, Wu C-L, Su L-K, Gorka C, Nelson C, Harlow E, Tsai L-H (1992) A family of human cdc2-related protein kinases. EMBO J 11:2909-2917.

Montarolo PG, Goelet P, Castellucci VF, Morgan J, Kandel ER, Schacher S (1986) A critical period for macromolecular synthesis in long-term heterosynaptic facilitation in Aplysia. Science 234:1249-1254.

Nishida E, Gotoh Y (1993) The MAP kinase cascade is essential for diverse signal transduction pathways. Trends Biochem Sci 18:128-131.

Nordholm AF, Thompson JK, Dersarkissian C, Thompson RF (1993) Lidocaine infusion in a critical region of cerebellum completely pre- vents learning of the conditioned eyeblink response. Behav Neurosci 107:882-886.

Shibuki K, Gomi H, Chen L, Bao S, Kim JJ, Wakatsuki H, Fujisaki T, Fujimoto K, Katoh A, Ikeda T, Chen C, Thompson RF, Itohara S (1996) Deficient cerebellar long-term depression, impaired eyeblink conditioning, and normal motor coordination in GFAP mutant mice. Neuron 16:587-599.

Silva AJ, Paylor R, Wehner JM, Tonegawa S (1992) Impaired spatial learning in alpha-calcium-calmodulin kinase II mutant mice. Science 257:206-211.

Soderling TR (1993) Calcium/calmodulin-dependent protein kinase II: role in learning and memory. Mol Cell Biochem 127-128:93-101.

Soppet DR, Beasley LL, Willard MB (1991) Sequence of the rabbit neurofilament protein L. J Neurosci Res 30:42-46.

Steinmetz JE, Lavond DG, Ivkovich D, Logan CG, Thompson RF (1992) Disruption of classical eyelid conditioning after cerebellar lesions: damage to a memory trace system or a simple performance deficit? J Neurosci 12:4403-4426.

Taglienti CA, Wysk M, Davis RJ (1996) Molecular cloning of the epidermal growth factor-stimulated protein kinase p56 KKIAMRE. Oncogene 13:2563-2574.

Tang D, Lee KY, Qi Z, Matsuura I, Wang JH (1996) Neuronal Cdc2like kinase: from cell cycle to neuronal function. Biochem Cell Biol 74:419-429.

Thompson RF (1986) The neurobiology of learning and memory. Science 233:941-947.

Thompson RF, Krupa DJ (1994) Organization of memory traces in the mammalian brain. Annu Rev Neurosci 17:519-549.

Tsai L-H, Harlow E, Meyerson M (1991) Isolation of the human cdk2 gene that encodes the cyclin A- and adenovirus E1A-associated p33 kinase. Nature 353:174-177.

Wang JH, Feng DP (1992) Postsynaptic protein kinase C essential to induction and maintenance of long-term potentiation in the hippocampal CA1 region. Proc Natl Acad Sci USA 89:2576-2580.

Yen S-H, Kenessey A, Lee SC, Dickson W (1995) The distribution and biochemical properties of a cdc2-related kinase, KKIALRE, in normal and Alzheimer brains. J Neurochem 65:2577-2584.

Yeo CH, Hardiman MJ, Glickstein M (1985a) Classical conditioning of the nictitating membrane response of the rabbit. I. Lesions of the cerebellar nuclei. Exp Brain Res 60:87-98.

Yeo CH, Hardiman MJ, Glickstein M (1985b) Classical conditioning of the nictitating membrane response of the rabbit. II. Lesions of the cerebellar cortex. Exp Brain Res 60:99-113.

Yin JCP, Wallach JS, Del Vacchio M, Wilder EL, Zhou HL, Quinn WG, Tully T (1994) Induction of a dominant negative CREB transgene specifically blocks long-term memory in Drosophila. Cell 79:49-58. 